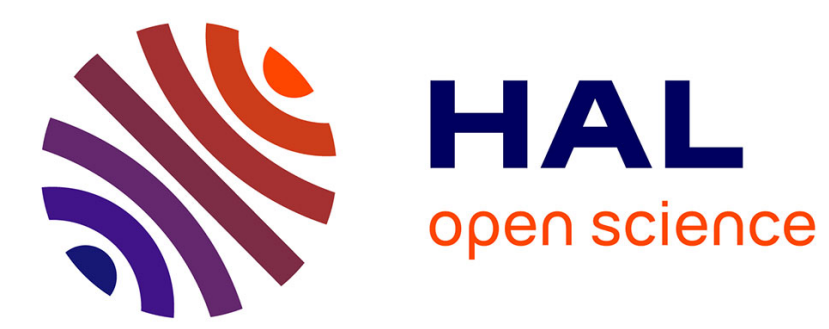

\title{
Impact of private labels and information campaigns on organic and fair trade food demand
}

\author{
Douadia Bougherara, Carole Ropars-Collet, Jude Saint-Gilles
}

\section{To cite this version:}

Douadia Bougherara, Carole Ropars-Collet, Jude Saint-Gilles. Impact of private labels and information campaigns on organic and fair trade food demand. 2018. hal-02790604

\section{HAL Id: hal-02790604 https://hal.inrae.fr/hal-02790604}

Preprint submitted on 5 Jun 2020

HAL is a multi-disciplinary open access archive for the deposit and dissemination of scientific research documents, whether they are published or not. The documents may come from teaching and research institutions in France or abroad, or from public or private research centers.
L'archive ouverte pluridisciplinaire HAL, est destinée au dépôt et à la diffusion de documents scientifiques de niveau recherche, publiés ou non, émanant des établissements d'enseignement et de recherche français ou étrangers, des laboratoires publics ou privés. 


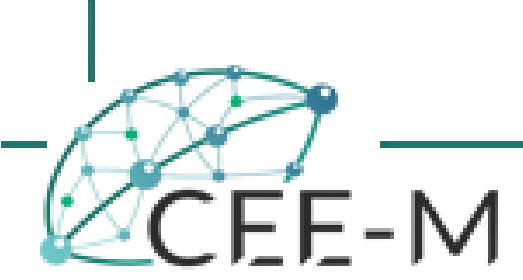

CENTER FOR ENVIRONMENTAL ECONOMICS - MONTPELLIER

Impact of private labels and information campaigns on organic and fair trade food demand

Douadia Bougherara

Carole Ropars-Collet

$\&$ Jude Saint-Gilles

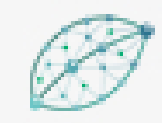

CEE-M Working Paper 2018-09 


\title{
Impact of private labels and information campaigns on organic and fair trade food demand
}

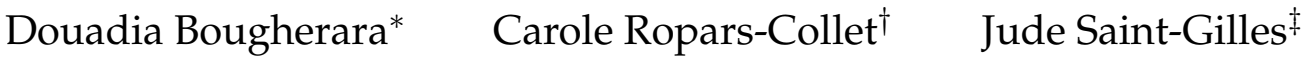

\begin{abstract}
We use Almost Ideal Demand Systems (AIDS) models estimated by the nonlinear seemingly unrelated regression (SUR) method on scanner data (i) to examine the demand for ecolabeled food products (organic and fair trade) as a function of the good having a private label (PL) or a national brand (NB) and (ii) to assess the impact of information campaigns promoting organic and fair trade products. We find that while demand is elastic for NB organic milk and NB fair trade coffee, it is inelastic for their PL counterpart. As for organic eggs, demand is always inelastic. Cross-price elasticities show substitutability between ecolabeled and conventional goods but only within the NB goods (milk and eggs) and within the PL goods (milk and coffee), but also complementarity between NB conventional and PL ecolabeled goods (milk and coffee). Finally, we find that while information campaigns increase the predicted expenditure shares of PL organic milk by $33 \%$, of NB fair trade coffee by $50 \%$, they decrease the predicted expenditure shares of PL conventional eggs but only by $3 \%$. These effects are non-lasting.
\end{abstract}

Keywords: Organic; Fair trade; Information campaign;

JEL Classification: D12 (Consumer Economics: Empirical Analysis); Q5 (Environmental Economics); D82 (Asymmetric and Private Information, Mechanism Design).

\footnotetext{
*CEE-M, Univ. Montpellier, CNRS, INRA, SupAgro, Montpellier, France.

${ }^{\dagger}$ AGROCAMPUS OUEST, UMR 1302 SMART-LERECO, Rennes, France. Corresponding author. Address: AGROCAMPUS OUEST, Département Economie Gestion Société, 65 rue de Saint-Brieuc, CS 84215, 35042 Rennes Cedex, France. Phone: +33 (0)2.23.48.56.91. E-mail: carole.ropars@agrocampus-ouest.fr †INRA, UMR 1302 SMART-LERECO, Rennes, France.
} 


\section{Background and motivation}

There are many labels pertaining to environmental and ethical performance of goods. Product labeling is considered as an environmental policy tool capable of driving consumers towards behaviors less harmful for the environment. Besides, information campaigns are also used to raise consumers awareness on the importance of sustainable consumption. Research has focused on a number of issues related to the efficiency of labeling. One constant concern is to elicit consumer preferences for process attributes of goods. The careful design of surveys and statistical methods aim to measuring this unobservable. In this article, we contribute to that literature by estimating a demand system for two organic products and one fair trade product, as a function of the good having a private label (PL) or a national brand (NB), using French scanner data at an aggregate level in a period where retailers began to play an important role in these markets.

Eliciting consumer preferences from scanner data can be a challenge because of the many sources of variation but it has a strong external validity (real purchases). Table 1 reviews all the articles to our knowledge (19 articles) that elicit preferences for ecolabeled goods using scanner data. Several comments follow. (i) Samples are bigger than survey samples (stated choice surveys, experiments, etc.) and are usually more representative. (2) Scanner data are time series that enable to take account of time trend and allow to take account of consumer preference heterogeneity. (3) The main label considered in these papers is the organic label (11 articles). Only four articles have considered the fair trade label. (4) The main estimation technique is the Almost Ideal Demand System model (Deaton and Muellbauer, 1980) that enables to take account of substitution and revenue effects. All these studies, except Jonas and Roosen (2008), Anders and Moeser (2008), Alviola and Capps (2010), use the AIDS model at an aggregate level. (5) Nine studies use US data. (6) Six of the 19 articles on food products deal with milk. (7) Most estimated own-price elasticities show demand for ecolabeled goods is elastic and sometimes very elastic. (8) Estimated cross-price elasticities show that ecolabeled goods and their conventional counterpart are substitutes except for meat (complements). (9) Estimated expenditure elasticities are mainly positive (except for ground meat) and smaller than 2 , sometimes smaller than unit. 
Table 1: Articles using scanner data to elicit preferences for ecolabeled products.

\begin{tabular}{|c|c|c|c|}
\hline $\begin{array}{l}\text { Empirical } \\
\text { strategy }\end{array}$ & $\begin{array}{l}\text { Country, sample size, } \\
\text { and period }\end{array}$ & $\begin{array}{l}\text { Product and } \\
\text { label }\end{array}$ & Main results for ecolabeled goods \\
\hline \multicolumn{4}{|c|}{ Glaser and Thompson (1998) } \\
\hline $\begin{array}{l}\text { Demand system } \\
\text { estimation } \\
\text { (aggregate) }\end{array}$ & $\begin{array}{l}\text { US } \\
\text { Weekly purchases } \\
\text { 3,000 supermarkets } \\
\text { Sept 1990-Dec } 1996\end{array}$ & $\begin{array}{l}\text { Frozen vegetables } \\
\text { (Broccoli, green beans, } \\
\text { green peas, sweet corn) } \\
\text { Organic }\end{array}$ & $\begin{array}{l}\text { - Own-price elasticities: }-1.63 \text { to }-2.27 \text {; } \\
2-3 \text { times higher than for conventional } \\
\text { counterparts; } \\
\text { - Cross-price elasticities: weak evidence } \\
\text { of substitution between organic and } \\
\text { conventional goods; asymmetries between } \\
\text { conventional and organic good; } \\
\text { - Expenditure elasticities: } 0.78 \text { to } 1.49 \text {; }\end{array}$ \\
\hline \multicolumn{4}{|c|}{ Glaser and Thompson (2000) } \\
\hline $\begin{array}{l}\text { Demand system } \\
\text { estimation } \\
\text { (aggregate) }\end{array}$ & $\begin{array}{l}\text { US } \\
\text { Monthly purchases } \\
\text { 3,000 supermarkets } \\
\text { 1996-1999 }\end{array}$ & $\begin{array}{l}4 \text { types of milk } \\
\text { (4 fat contents) } \\
\text { Organic }\end{array}$ & $\begin{array}{l}\text { - Own-price elasticities: }-9.73 \text { to }-3.64 \text {; } \\
\text { - Cross-price elasticities: negative between } \\
\text { organic milk and conventional milk except } \\
\text { for } 1 \% \text { fat milk (positive); asymmetries } \\
\text { between conventional and organic milk; } \\
\text { - Expenditure elasticities: }-8.68 \text { to }-2.81 \text {; }\end{array}$ \\
\hline \multicolumn{4}{|c|}{ Teisl, Roe, and Hicks (2002) } \\
\hline $\begin{array}{l}\text { Demand system } \\
\text { estimation } \\
\text { (aggregate) }\end{array}$ & $\begin{array}{l}\text { US } \\
\text { Monthly purchases } \\
\text { 3,000 supermarkets } \\
\text { Apr 1988-Dec } 1995\end{array}$ & $\begin{array}{l}\text { Tuna } \\
\text { Dolphin-safe }\end{array}$ & $\begin{array}{l}\text { - Positive impact of label on tuna purchase } \\
\text { over a period of several months; }\end{array}$ \\
\hline \multicolumn{4}{|c|}{ Armand-Balmat (2002) } \\
\hline $\begin{array}{l}\text { Demand system } \\
\text { estimation } \\
\text { (aggregate) }\end{array}$ & $\begin{array}{l}\text { France } \\
\text { Weekly purchases } \\
98 \text { supermarkets } \\
\text { Jul 1998-Dec } 1999\end{array}$ & $\begin{array}{l}\text { Steak beef } \\
\text { Organic }\end{array}$ & $\begin{array}{l}\text { - Own-price elasticities: }-2.23 \text {; } \\
\text { - Cross-price elasticities: positive between } \\
\text { organic steak and conventional counterpart; } \\
\text { - Expenditure elasticities: } 1.06 \text {; } \\
\text { - WTP for organic attribute is around } \\
3 \% \text { of total expenses; }\end{array}$ \\
\hline \multicolumn{4}{|c|}{ Galarraga and Markandya (2004) } \\
\hline $\begin{array}{l}\text { Hedonic price model } \\
\text { and demand system } \\
\text { estimation } \\
\text { (aggregate) }\end{array}$ & $\begin{array}{l}\text { UK } \\
5 \text { supermarkets } \\
1997-1998\end{array}$ & $\begin{array}{l}\text { Coffee } \\
\text { Fair trade }\end{array}$ & $\begin{array}{l}\text { - Hedonic price results: } 11.26 \% \text { premium; } \\
\text { - Own-price elasticities: demand } \\
\text { for fair trade coffee more elastic than } \\
\text { demand for conventional counterpart; }\end{array}$ \\
\hline \multicolumn{4}{|c|}{ Bjorner, Hansen, and Russell (2004) } \\
\hline Mixed Logit & $\begin{array}{l}\text { Denmark } \\
\text { Weekly purchases } \\
\text { Jan 1997-Jan } 2001\end{array}$ & $\begin{array}{l}\text { Toilet paper, paper } \\
\text { towels, detergents } \\
\text { Nordic ecolabel }\end{array}$ & $\begin{array}{l}\text { - Positive impact on choice of toilet } \\
\text { paper; impact less clear for paper towels } \\
\text { and detergents; } \\
\text { - Positive impact of information (consumer } \\
\text { reports or ecolabel) on choice of } \\
\text { detergents; } \\
\text { - WTP around 13-18\% of price for toilet } \\
\text { paper; }\end{array}$ \\
\hline \multicolumn{4}{|c|}{ Boizot-Szantai, Lecocq, and Marette (2005) } \\
\hline $\begin{array}{l}\text { Demand system } \\
\text { estimation } \\
\text { (aggregate) }\end{array}$ & $\begin{array}{l}\text { France } \\
\text { Weekly purchases } \\
4 \text { years }(1993,1996,1999,2002)\end{array}$ & $\begin{array}{l}\text { Eggs } \\
\text { Organic }\end{array}$ & $\begin{array}{l}\text { - Own-price elasticity in 2002: }-0.95 \\
\text { - Expenditure elasticity: } 1.98\end{array}$ \\
\hline \multicolumn{4}{|l|}{ Dhar and Foltz (2005) } \\
\hline $\begin{array}{l}\text { Demand system } \\
\text { estimation } \\
\text { (aggregate) }\end{array}$ & $\begin{array}{l}\text { US } \\
\text { Weekly purchases } \\
12 \text { cities in } 4 \text { regions } \\
\text { Mar 1997-Feb } 2002\end{array}$ & $\begin{array}{l}\text { Milk } \\
\text { Organic } \\
\text { and hormone-free (rBST- } \\
\text { Bovine Somatotropin) }\end{array}$ & $\begin{array}{l}\text { - Own-price elasticities: }-1.37 \text {; } \\
\text { - Cross-price elasticities: unlabeled milk; } \\
\text { is a substitute for both rBST-free and } \\
\text { organic milk; rBST-free and organic milk }\end{array}$ \\
\hline
\end{tabular}


Table 1 - continued from previous page

\begin{tabular}{|c|c|c|c|}
\hline $\begin{array}{l}\text { Empirical } \\
\text { strategy }\end{array}$ & $\begin{array}{l}\text { Country, sample size, } \\
\text { and period }\end{array}$ & $\begin{array}{l}\text { Product and } \\
\text { label }\end{array}$ & Main results for ecolabeled goods \\
\hline & & & $\begin{array}{l}\text { are complements; } \\
\text { - Expenditure elasticities:0.50 ; }\end{array}$ \\
\hline \multicolumn{4}{|c|}{ Arnot, Boxall, and Cash (2006) } \\
\hline $\begin{array}{l}\text { Random utility } \\
\text { choice model }\end{array}$ & $\begin{array}{l}\text { Canada } \\
\text { Daily purchases } \\
\text { Experiment in cooperation } \\
\text { with a brewed coffee vendor } \\
474 \text { individuals surveyed }\end{array}$ & $\begin{array}{l}\text { Coffee } \\
\text { Fair trade }\end{array}$ & $\begin{array}{l}\text { - Own-price elasticities of purchase } \\
\text { probability: -0.42; } 3-4 \text { times lower } \\
\text { than for conventional coffee; } \\
\text { - Cross-price elasticities of purchase } \\
\text { probability: fair trade and conventional } \\
\text { coffee are substitutes with asymmetries; } \\
\text { Low elasticities for conventional coffee } \\
\text { as the price of fair trade coffee } \\
\text { increases; }\end{array}$ \\
\hline \multicolumn{4}{|c|}{ Kiesel and Villa-Boas (2007) } \\
\hline $\begin{array}{l}\text { Hedonic price } \\
\text { function and random } \\
\text { utility discrete } \\
\text { choice model }\end{array}$ & $\begin{array}{l}\text { US } \\
\text { Daily purchases } \\
\text { 927 households } \\
2000-2003\end{array}$ & $\begin{array}{l}\text { Milk } \\
\text { Organic } \\
\text { and hormone-free (rBGH- } \\
\text { Bovine Growth Hormone) }\end{array}$ & $\begin{array}{l}\text { - Labeling a milk product as organic } \\
\text { increases the choice probability of } \\
\text { purchasing; }\end{array}$ \\
\hline \multicolumn{4}{|c|}{ Jonas and Roosen (2008) } \\
\hline $\begin{array}{l}\text { Demand system } \\
\text { estimation with } \\
\text { 2-step procedure }\end{array}$ & $\begin{array}{l}\text { Germany } \\
\text { Yearly purchases } \\
7,768 \text { households } \\
2000-2003\end{array}$ & $\begin{array}{l}\text { Milk } \\
\text { Organic }\end{array}$ & $\begin{array}{l}\text { - Own-price elasticity: -9.85; } \\
\text { - Cross-price elasticities: organic milk } \\
\text { and conventional milk are substitutes; } \\
\text { - Expenditure elasticity: } 0.73 \text {; }\end{array}$ \\
\hline \multicolumn{4}{|c|}{ Anders and Moeser (2008) } \\
\hline $\begin{array}{l}\text { Demand system } \\
\text { estimation }\end{array}$ & $\begin{array}{l}\text { Canada } \\
\text { Weekly purchases } \\
9,000 \text { households } \\
\text { Dec 2000-Jul 2007 }\end{array}$ & $\begin{array}{l}\text { Steak, roast and ground } \\
\text { beef } \\
\text { Organic }\end{array}$ & $\begin{array}{l}\text { - Own-price elasticities: -0.78 (steak); } \\
-0.61 \text { (roast); - } 3.24 \text { (ground); } \\
\text { - Cross-price elasticities: complementarity } \\
\text { among organic beef cuts; complementarity or } \\
\text { substitution between organic } \\
\text { and conventional counterpart; } \\
\text { - Expenditure elasticities: } 1.93 \text { (steak); } \\
1.70 \text { (roast); -2.87 (ground); }\end{array}$ \\
\hline \multicolumn{4}{|c|}{ Monier, Hasssan, Nichèle, and Simioni (2009) } \\
\hline $\begin{array}{l}\text { Market basket } \\
\text { model and demand } \\
\text { system estimation } \\
\text { (aggregate) }\end{array}$ & $\begin{array}{l}\text { France } \\
\text { Weekly purchases } \\
10,000 \text { households } \\
2005\end{array}$ & $\begin{array}{l}\text { Eggs and milk } \\
\text { Organic }\end{array}$ & $\begin{array}{l}\text { - Choice of one organic good increases the } \\
\text { probability of choosing an organic good of } \\
\text { another product category; } \\
\text { - Reductions in price of organic good does } \\
\text { not increase the probability of purchasing } \\
\text { organic good of another category; } \\
\text { - Own-price elasticities: -2.38 (eggs); } \\
\text { non-significant (milk); }\end{array}$ \\
\hline \multicolumn{4}{|c|}{ Casadesus-Masanell, Crooke, Reinhardt, and Vasishth (2009) } \\
\hline $\begin{array}{l}\text { Difference-in- } \\
\text { difference } \\
\text { estimation }\end{array}$ & $\begin{array}{l}\text { US } \\
\text { All purchases } \\
\text { 9,349 households } \\
\text { 1994-1997 }\end{array}$ & $\begin{array}{l}\text { Cotton shirts } \\
\text { Organic }\end{array}$ & $\begin{array}{l}\text { - Consumers were willing to pay } \$ 6.58 \\
\text { more for organic cotton shirts (compared to } \\
\text { conventional cotton shirts) that is } 114.6 \% \\
\text { of the increase in production cost; }\end{array}$ \\
\hline \multicolumn{4}{|c|}{ Alviola and Capps (2010) } \\
\hline $\begin{array}{l}\text { Demand system } \\
\text { estimation with } \\
\text { 2-step procedure }\end{array}$ & $\begin{array}{l}\text { US } \\
\text { Yearly purchases } \\
38,000 \text { households } \\
2004\end{array}$ & $\begin{array}{l}\text { Milk } \\
\text { Organic }\end{array}$ & $\begin{array}{l}\text { - Own-price elasticities: }-2.00 ; \\
\text { - Cross-price elasticities: organic milk } \\
\text { and conventional milk are substitutes } \\
\text { but with asymmetries; } \\
\text { - Expenditure elasticity: } 0.27\end{array}$ \\
\hline \multicolumn{4}{|c|}{ Roheim, Asche, and Santos (2011) } \\
\hline Hedonic price & UK & Frozen processed & - Hedonic price results: $14.2 \%$ premium; \\
\hline
\end{tabular}

Continued on next page 
Table 1 - continued from previous page

\begin{tabular}{|c|c|c|c|}
\hline $\begin{array}{l}\text { Empirical } \\
\text { strategy }\end{array}$ & $\begin{array}{l}\text { Country, sample size, } \\
\text { and period }\end{array}$ & $\begin{array}{l}\text { Product and } \\
\text { label }\end{array}$ & Main results for ecolabeled goods \\
\hline function & $\begin{array}{l}\text { Weekly purchases } \\
\text { Feb 2007-May } 2008\end{array}$ & $\begin{array}{l}\text { Alaska pollock products } \\
\text { MSC (Marine Stewardship } \\
\text { Council) }\end{array}$ & \\
\hline \multicolumn{4}{|l|}{ Schollenberg (2012) } \\
\hline $\begin{array}{l}\text { Hedonic price } \\
\text { function }\end{array}$ & $\begin{array}{l}\text { Sweden } \\
\text { Weekly purchases } \\
\text { 2005-2008 }\end{array}$ & $\begin{array}{l}\text { Coffee } \\
\text { Fair trade }\end{array}$ & - Hedonic price results: 38\% premium; \\
\hline \multicolumn{4}{|c|}{ Hainmueller, Hiscox, and Sequeira (2015) } \\
\hline Field experiment & $\begin{array}{l}\text { US (4 states) } \\
26 \text { stores of major US } \\
\text { grocery store chain } \\
\text { Oct-Dec 2008; Jun-Aug 2009; }\end{array}$ & $\begin{array}{l}\text { Coffee } \\
\text { Fair trade }\end{array}$ & $\begin{array}{l}\text { - Label experiment: demand increased by } \\
\text { 10\% for labeled coffee; switch from } \\
\text { non-Fair Trade to Fair Trade coffee for } \\
\text { close substitute in terms of taste; } \\
\text { - Price experiment: consumers buying } \\
\text { the lower-priced coffee are price sensitive; } \\
\text { consumers buying the higher-priced coffee } \\
\text { are willing to pay an } 8 \% \text { premium; }\end{array}$ \\
\hline \multicolumn{4}{|c|}{ Sun, Chiang, Owens, and Squires (2017) } \\
\hline $\begin{array}{l}\text { Demand system } \\
\text { estimation } \\
\text { (aggregate) }\end{array}$ & $\begin{array}{l}\text { US } \\
\text { Weekly purchases } \\
\text { Conventional and natural } \\
\text { supermarkets } \\
\text { Sep 2008-Sep } 2011\end{array}$ & $\begin{array}{l}\text { Eco-friendly label } \\
\text { canned tuna }\end{array}$ & $\begin{array}{l}\text { - Own-price elasticities: }-3.1 ; \\
\text { - Cross-price elasticity: Substitution } \\
\text { between eco-friendly canned tuna } \\
\text { and conventional counterpart; } \\
\text { - Expenditure elasticities: } 1.88 ;\end{array}$ \\
\hline
\end{tabular}

In this paper, our aim is twofold. First, we use scanner data to estimate demand for organic and fair trade food products as a function of the good having a NB or a PL. None of the articles found in the literature consider the impact of the product having a PL or a NB. Green goods are now easily found in big retail stores and not only in specialized stores. The strategy of retailers can be to sell green goods either with the manufacturer's own brand or with its private label. Private labels are brands owned and controlled by retailers and serve two objectives: they increase the retailer's bargaining power for products with high substitutability (me-too products) and enable price discrimination (low or high price products) (Berges-Sennou, Bontems, and Requillart, 2004). In the period considered in our study (2007-2008), large retailers began to play an important role in ecolabeled markets in France. From that time period, there is a debate among ecolabel promoters as to using major retail stores as a marketing channel.

Second, we determine the impact of information campaigns promoting organic and fair trade products. Two important information campaigns for organic and fair trade products are organized each year in France. They involve institutions as well as associations and broad citizen actions. As for organic food products, we focus on the role of a yearly information campaign called "Le Printemps Bio" (http:/ / www.printempsbio.com), The Organic Spring. "Le Printemps Bio" was lauched in 2000 and takes place every spring during two weeks (always from June 1st to June 15th). It is co-funded by the French government and the European Union under Council Regulation (EC) No. 2826/2000 on information and promotion actions for agri- 
cultural products on the internal market ${ }^{1}$ (Yussefi-Menzler, Willer, and Sorensen, 2010). Agence $\mathrm{Bio}^{2}$, the French agency for the promotion and development of organic farming, promotes the event. During The Organic Spring, several activities are organized such as open doors in farms, conferences, fairs, etc. As for fair trade products, The Fairtrade Fortnight has been launched in the 90 s in the UK and spread to several countries, e.g. Australia, New-Zealand. In France, The Fairtrade Fortnight called "La Quinzaine du Commerce Equitable" was launched early 2000s by the Plateforme pour le Commerce Équitable (PFCE), a French association of fair trade actors (http://www.commercequitable.org). In the period under consideration in our study, "La Quinzaine du Commerce Equitable" took place in 2007 from April 27th to May 13th and in 2008, from April 25th to May 11th. We introduce the two information campaigns as demand shifters in our demand system model and determine their impact on consumers expenditures on organic and fair trade products.

We use AIDS models estimated by the nonlinear seemingly unrelated regression (SUR) method on scanner data at an aggregate level (i) to examine the demand for ecolabeled food products as a function of the good having a private label (PL) or a national brand (NB) and (ii) to assess the impact of information campaigns promoting organic and fair trade products. We find that while demand is elastic for NB organic milk and NB fair trade coffee, it is inelastic for their PL counterpart. As for organic eggs, demand is always inelastic. Cross-price elasticities show substitutability between ecolabeled and conventional goods but only within the NB (milk and eggs) or within the PL (milk and coffee), but also complementarity between NB conventional and PL ecolabeled goods (milk and coffee). Finally, we find that while information campaigns increase the predicted expenditure shares of PL organic milk by $33 \%$, of NB fair trade coffee by $50 \%$, they decrease the predicted expenditure shares of PL conventional eggs but only by $3 \%$. These effects are non-lasting.

Our paper is organized as follows. In section 2, we describe our data. We specify our empirical model in section 3 . We present and discuss our estimate results in sections 4 and 5 . Section 6 concludes.

\section{Data and descriptive statistics}

We use a database of individual purchases of French households (14,024 in 2007 and 26,471 in 2008) from Données Kantar Worldpanel. We had access to a detailed database on consumption of food products for 2007 and 2008. Markets of ecolabeled products evolve very fast. Indeed, while the sales of the organic products was 2 billion euros in France in 2007, this one reached 7 billion in 2016 (a 278\% increase). This evolution took place in a context where the French consumers give more and more importance to the environmental protection ${ }^{3}$. Despite

\footnotetext{
${ }^{1}$ http://data.europa.eu/eli/reg/2000/2826/oj

${ }^{2}$ http://www.agencebio.org/

${ }^{3} 92 \%$ of respondents in 2016 vs. 67\% in 2007 in Barometer consumption Orders BIO / RESEARCH CSA, January 2017
} 
this evolution, we think we can learn from analyzing 2007-2008 data on organic and fair trade consumption. 2007-2008 is a period where large retailers began to play an important role in ecolabeled markets in France. Stores specialized in ecolabeled products were the main purchase channel until 2007. From 2008, large retailers became the first channel for ecolabeled product purchase $^{4}$. Large retailers not only sold ecolabeled products but began to ecolabel their own private labels ${ }^{5}$. Finally, there was and there still is a debate among organic and fair trade promoters about whether or not these products should be sold in large retail stores ${ }^{6}$. This is the reason why we consider the demand for ecolabeled products as a function of their having a private label or a national brand.

We focus on the aggregate demand. All consumers in the database are considered as one representative consumer. Because few households buy organic or fair trade products, we consider weekly purchases to avoid zero observations. We have then 104 observations corresponding to all weekly purchases for the two years under consideration. We focus on products for which purchases of the ecolabeled goods are high. We focus on three products in our data base: milk, eggs, and ground coffee.

Table 2 shows prices (per liter for milk, per egg and per $100 \mathrm{gr}$ for coffee) and premia for ecolabeled products. The organic premium is very high, up to $116 \%$ for eggs. The fair trade premium is high, up to $54 \%$. For organic and fair trade products, the premium is higher for NB products. For milk, the premium for NB products is higher for organic than for conventional, whereas for coffee, the premium for NB coffee is higher for conventional than for fair trade coffee. This indicates that the label seems to interact with the brand. We will allow for substitution effects between NB and PL products in the following econometric specification.

\footnotetext{
${ }^{4}$ Sia Partners INSIGHT, L'irrésistible croissance du bio en France, in May 2017. http://transport.siapartners.com/sites/default/files/lirresistible-croissance-du-bio-en-france.pdf

${ }^{5}$ http:/ / www.lefigaro.fr/conjoncture/2010/05/18/04016-20100518ARTFIG00639-la-grande-distribution-veutrester-equitable.php

${ }^{6}$ Jacquiau C., 2007, Pourquoi le Sud rue dans les brancards, Max Havelaar ou les ambiguïtés du commerce équitable, Le Monde Diplomatique, Septembre 2007.
} 
Table 2: Prices and premia for milk, eggs and coffee in 2007 and 2008 (per liter for milk, per egg and per $100 \mathrm{gr}$ for coffee)

\begin{tabular}{|c|c|c|c|c|c|c|c|c|c|c|c|c|}
\hline & \multicolumn{4}{|c|}{ Milk } & \multicolumn{4}{|c|}{ Eggs } & \multicolumn{4}{|c|}{ Coffee } \\
\hline & Org. & Conv. & $\Delta \underset{(€)}{\Delta \text { Org. }}$ & $\Delta$ Org. & Org. & Conv. & $\Delta \underset{(€)}{\Delta \text { Org. }}$ & $\Delta$ Org. & FT & Conv. & $\begin{array}{r}\Delta \mathrm{FT} \\
(€)\end{array}$ & $\begin{array}{r}\Delta \mathrm{FT} \\
(\%)\end{array}$ \\
\hline \multicolumn{13}{|l|}{ In 2007} \\
\hline $\begin{array}{l}\text { Private Label } \\
\text { National Brand } \\
\triangle \mathrm{NB}(€) \\
\Delta \mathrm{NB}(\%)\end{array}$ & $\begin{array}{r}0.98 \\
1.33 \\
0.35 \\
26.31\end{array}$ & $\begin{array}{l}0.68 \\
0.74 \\
0.06 \\
8.10\end{array}$ & $\begin{array}{l}0.30 \\
0.59\end{array}$ & $\begin{array}{l}44.12 \\
79.73\end{array}$ & $\begin{array}{r}0.30 \\
0.39 \\
0.09 \\
23.08\end{array}$ & $\begin{array}{r}0.15 \\
0.18 \\
0.03 \\
16.67\end{array}$ & $\begin{array}{l}0.15 \\
0.21\end{array}$ & $\begin{array}{l}100.00 \\
116.67\end{array}$ & $\begin{array}{r}0.87 \\
1.11 \\
0.24 \\
21.62\end{array}$ & $\begin{array}{r}0.56 \\
0.77 \\
0.21 \\
27.27\end{array}$ & $\begin{array}{l}0.31 \\
0.34\end{array}$ & $\begin{array}{l}44.28 \\
44.15\end{array}$ \\
\hline \multicolumn{13}{|l|}{ In 2008} \\
\hline $\begin{array}{l}\text { Private Label } \\
\text { National Brand } \\
\Delta \mathrm{NB}(€) \\
\Delta \mathrm{NB}(\%)\end{array}$ & $\begin{array}{r}1.09 \\
1.55 \\
0.46 \\
29.68\end{array}$ & $\begin{array}{l}0.80 \\
0.81 \\
0.01 \\
1.23\end{array}$ & $\begin{array}{l}0.29 \\
0.74\end{array}$ & $\begin{array}{l}36.25 \\
91.35\end{array}$ & $\begin{array}{r}0.36 \\
0.41 \\
0.05 \\
12.19\end{array}$ & $\begin{array}{l}0.19 \\
0.19 \\
0.00 \\
0.00\end{array}$ & $\begin{array}{l}0.17 \\
0.22\end{array}$ & $\begin{array}{r}89.47 \\
115.79\end{array}$ & $\begin{array}{r}0.91 \\
1.13 \\
0.22 \\
19.47\end{array}$ & $\begin{array}{r}0.59 \\
0.79 \\
0.20 \\
25.32\end{array}$ & $\begin{array}{l}0.32 \\
0.34\end{array}$ & $\begin{array}{l}54.24 \\
43.03\end{array}$ \\
\hline
\end{tabular}

Data source: Données Kantar Worldpanel. Org., FT, Conv., NB and PL respectively stand for organic, fair trade, conventional, national brand and private label. $\Delta$ Org and $\Delta$ FT respectively stand for organic premium and fair trade premium. $\Delta$ NB stands for national brand premium.

\section{Empirical specification}

We use the Almost Ideal Demand System developed by Deaton and Muellbauer (1980), consistent with the requirements of the demand theory and extensively used in empirical works. Following this literature, we assume that each product expenditure is weakly separable from others purchases. In the AIDS model, the expenditure share equation for commodity $i$ is written as in Equation 1.

$$
w_{i}=\alpha_{i}+\sum_{j=1}^{K} \gamma_{i j} \log p_{j}+\beta_{i} \log \left(\frac{E x p}{P^{*}}\right)+\epsilon_{i}
$$

with $i=1, \ldots, K$

Where $w_{i}$ is the expenditure share for good $i, p_{j}$ is the price paid for good $j$ and Exp is the total expenditure on all goods in the demand system. We use $P^{*}$ as the Stone price index calculated as in Equation 2.

$$
\log P^{*}=\sum_{i=1}^{K} w_{i} \log p_{i}
$$

In order to avoid endogeneity problems due to the presence of expenditure shares $w_{i}$ in this calculated index, we replace them with their means $\bar{w}_{i}$, as Monier, Hasssan, Nichèle, and Simioni (2009). The price index used is as Equation 3.

$$
\log P^{*}=\sum_{i=1}^{K} \bar{w}_{i} \log p_{i}
$$

Following demand theory, we must have the following restrictions. The adding-up condi- 
tion requires several constraints on parameters: $\sum_{i=1}^{K} \alpha_{i}=1, \sum_{i=1}^{K} \beta_{i}=0$ and $\sum_{i=1}^{K} \gamma_{i j}=0 \forall j$. Since demand functions are homogeneous of degree zero in price and expenditure, we must impose $\sum_{j=1}^{K} \gamma_{i j}=0 \forall i$. Moreover, Slutsky symmetry implies that $\gamma_{i j}=\gamma_{j i}$.

Expenditure share systems were estimated for milk, eggs, and coffee, using the AIDS model previously described. We assume that each product (milk, eggs, and coffee) expenditure is weakly separable from each other and also from other purchases. For the two product categories, milk and eggs, we distinguished between expenditure shares of organic products and conventional ones, with national brand or private label. For coffee, we make the distinction between expenditure shares of coffee with the fair trade label, and conventional coffee, NB and PL coffee.

Engel curves were estimated by a nonparametric method (kernel regression). The curves on Figures 1, 2 and 3 present the expenditure shares for milk, eggs and coffee. These curves give the shape of expenditure shares for each product type depending on the total expenditure for the product category. For each year, the curves show a linear relationship between each expenditure shares of each product and total expenditure. Analysis of Engel curves on each year (not shown here) confirms linearity. As a result, we choose a rank 2 demand specification ${ }^{7}$ for milk, eggs and coffee (AIDS model).

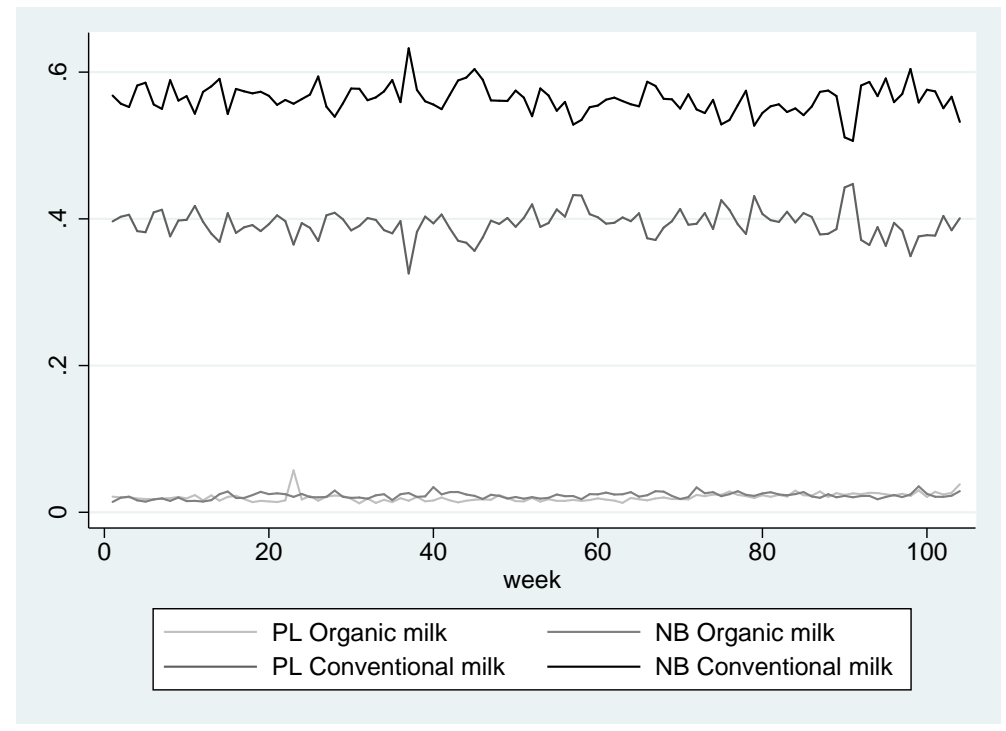

Figure 1: Expenditure shares for milk

The type of product we chose suggests we take into account seasonal household purchases. Therefore, we use control variables for seasons, and add to each expenditure share equations dummy variables for seasons ( $S_{1}$ for Winter, $S_{2}$ for Spring and $S_{3}$ for Summer with Fall being the reference). Since the data show an increase in purchases of ecolabeled products across year 2007 and 2008, we added a dummy variable for years (Year2008=1 if year 2008 and 0 if year 2007). We also account for information campaigns in Spring with a dummy

\footnotetext{
${ }^{7}$ This choice was confirmed since we added a quadratic term on expenditure for the expenditure shares system for each product, but the associated coefficient was not significant.
} 


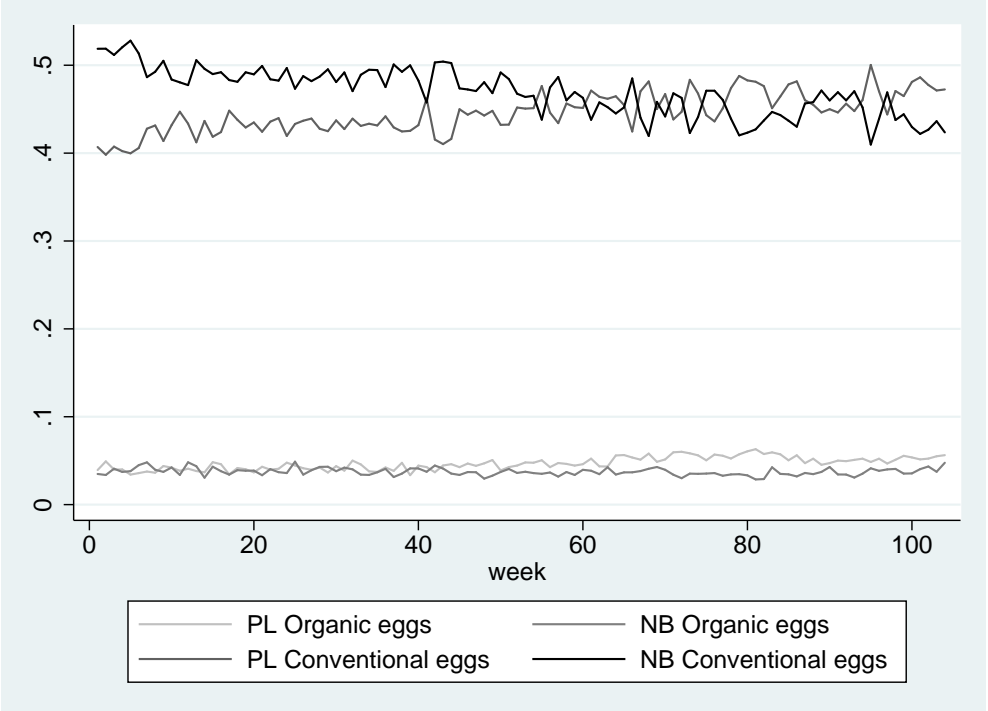

Figure 2: Expenditure shares for eggs

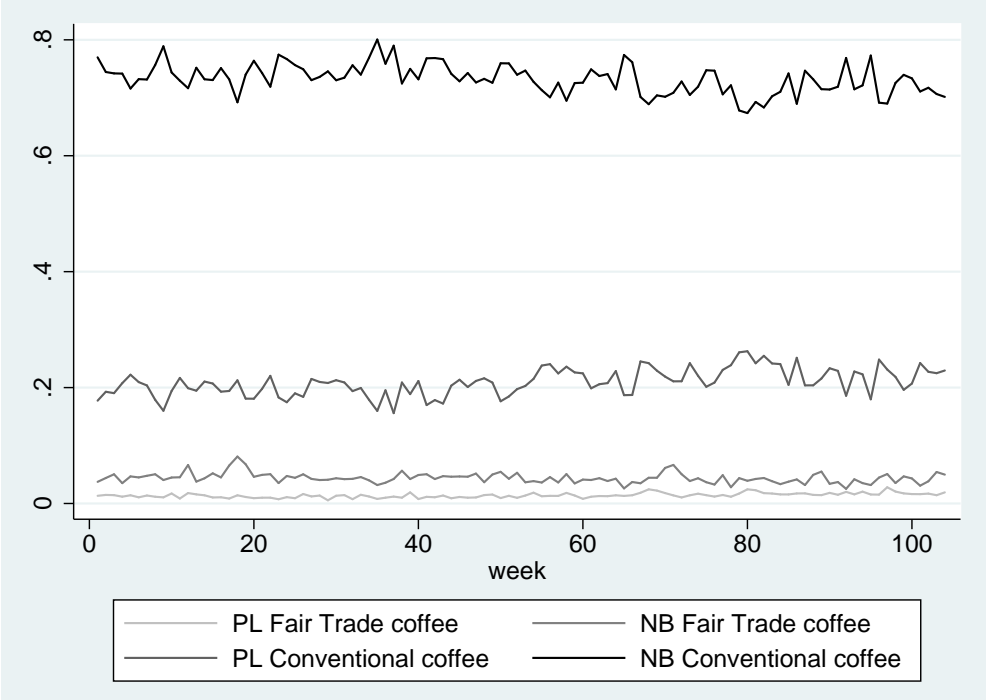

Figure 3: Expenditure shares for coffee 
InformationCampaign equal to one during the Organic Spring or The Fairtrade Fortnight campaign and zero otherwise. The Organic Spring, "Le Printemps Bio", for organic product information campaign, took place from June 1st till June 15th in 2007 and 2008. The Fairtrade Fornight, "La Quinzaine du Commerce Equitable", for fair trade product information campaign, took place from April 27th till May 13th in 2007 and from April 25th till May 11th in 2008. We interact that information campaign dummy with the Spring dummy. For milk, eggs and coffee, specification of AIDS demand systems is as in Equation 4.

$w_{i}=\alpha_{i}+\sum_{j=1}^{K} \gamma_{i j} \log p_{j}+\beta_{i} \log \left(\frac{\text { Exp }}{P^{*}}\right)+\theta_{i}$ Year2008 $+\kappa_{i}$ InformationCampaign $\times S_{2}+\sum_{s=1}^{3} \mu_{i s} S_{t}+\epsilon_{i}$

with $i=1, \ldots, K$.

The adding-up condition requires $\sum_{i=1}^{K} \theta_{i}=0, \sum_{i=1}^{K} \kappa_{i}=0, \sum_{i=1}^{K} \mu_{i s}=0$, in addition to the above conditions.

For milk and eggs, we consider four kinds of product: NB organic, PL organic, NB conventional, and PL conventional. For coffee, we also consider four kinds of products: NB fair trade, PL fair trade, NB conventional, and PL conventional.

The elasticities are estimated from results of the estimated AIDS models, at the mean of the variables. The uncompensated price elasticities are calculated using Equation 5.

$$
\epsilon_{i j}=-\delta_{i j}+\frac{\gamma_{i j}}{w_{i}}-\beta_{i} \frac{w_{j}}{w_{i}}
$$

With $\delta_{i j}=0$ if $i \neq j$ and $\delta_{i j}=1$ if $i=j$

Expenditure elasticities are presented in Equation 6.

$$
\eta_{i}=1+\frac{\beta_{i}}{w_{i}}
$$

Compensated price elasticities are calculated from uncompensated price and expenditure elasticities using Equation 7.

$$
\epsilon_{i j}^{c}=\epsilon_{i j}+w_{j} \eta_{i}
$$

\section{Estimating the demand for ecolabeled food product}

As mentioned before, econometric analyses are based on weekly aggregate purchases data over the years 2007 and 2008. There are 104 observations for each product. Weekly expenditure shares of each type of product are estimated depending on the weekly average price of each type of product for the category considered, the total expenditure for the category, a year dummy, an information campaign dummy and seasonal dummies. The demand systems are estimated by iterative seemingly unrelated regression (SUR), with the restrictions of eco- 
nomic theory imposed. We first present the estimation results for milk and eggs (organic vs. conventional, NB vs. PL) then the results for coffee (fair trade vs. conventional, NB vs. PL).

\subsection{Demand for organic milk and eggs}

Estimates of the AIDS models for milk and eggs are presented in Table 3. Because of the addingup condition, one equation has been deleted from each system. Demand systems were estimated omitting NB conventional milk in the milk system and omitting NB conventional eggs in the egg system. We do not present parameters for the expenditure shares for these products but we calculated them from the constraints on the demand systems in order to calculate price and expenditure elasticities (see Table 4). All the elasticities (compensated and uncompensated) are calculated at the sample mean of variables.

As for the AIDS models in Table 3, the log likelihood ratio tests show the joint significance of all parameters for the milk system on the one hand and for the egg system on the other hand. We find that an increase in expenditure has a significant and negative impact on the expenditure share for all products except for PL organic milk and NB organic eggs (not significant). Both the milk and the egg models show a significant positive coefficient on the year dummy for the organic products except for PL organic milk, which indicates an upward trend of the expenditure share of these products across years. Season has an impact on expenditures for all products except for PL organic milk. Seasonal effects correspond to a seasonal variation in product consumption depending on product type (for example, ice cream in summer) but also other effects such as promotions. Our specification enables to isolate the impact of the Organic Spring (see Section 5). 
Table 3: Estimated AIDS model for milk and eggs

\begin{tabular}{|c|c|c|c|c|c|c|}
\hline & \multicolumn{3}{|c|}{ Milk } & \multicolumn{3}{|c|}{ Eggs } \\
\hline & PL Org. & NB Org. & PL Conv. & PL Org. & NB Org. & PL Conv. \\
\hline Constant & $\begin{array}{c}0.055 \\
(0.044)\end{array}$ & $\begin{array}{l}0.108^{* * *} \\
(0.029)\end{array}$ & $\begin{array}{c}0.760^{* * *} \\
(0.152)\end{array}$ & $\begin{array}{c}0.244^{* * *} \\
(0.048)\end{array}$ & $\begin{array}{l}0.092^{* *} \\
(0.047)\end{array}$ & $\begin{array}{c}0.772^{* * *} \\
(0.161)\end{array}$ \\
\hline \multicolumn{7}{|l|}{ Log(Price) } \\
\hline $\begin{array}{l}\text { PL Org. } \\
\text { NB Org. } \\
\text { PL Conv. }\end{array}$ & $\begin{array}{c}0.004 \\
(0.012) \\
0.011 \\
(0.006) \\
0.063^{* *} \\
(0.028)\end{array}$ & $\begin{array}{c}0.010 \\
(0.006) \\
-0.038^{* * *} \\
(0.008) \\
-0.043^{*} \\
(0.025)\end{array}$ & $\begin{array}{l}0.063^{* *} \\
(0.028) \\
-0.025 \\
(0.040) \\
-0.043^{*} \\
(0.025)\end{array}$ & $\begin{array}{c}0.038 \\
(0.027) \\
-0.010 \\
(0.014) \\
-0.005 \\
(0.023)\end{array}$ & $\begin{array}{c}-0.010 \\
(0.015) \\
0.032^{* *} \\
(0.015) \\
-0.039^{* *} \\
(0.017)\end{array}$ & $\begin{array}{c}-0.005 \\
(0.023) \\
-0.009 \\
(0.048) \\
-0.039^{* *} \\
(0.017)\end{array}$ \\
\hline $\log \left(\operatorname{Exp} . / P^{*}\right)$ & $\begin{array}{l}-0.004 \\
(0.004)\end{array}$ & $\begin{array}{c}-0.007^{* *} \\
(0.003)\end{array}$ & $\begin{array}{c}-0.042^{* * *} \\
(0.016)\end{array}$ & $\begin{array}{c}-0.021^{* * *} \\
(0.005)\end{array}$ & $\begin{array}{l}-0.008 \\
(0.005)\end{array}$ & $\begin{array}{l}-0.032^{*} \\
(0.017)\end{array}$ \\
\hline Year2008 & $\begin{array}{c}0.000 \\
(0.003)\end{array}$ & $\begin{array}{l}0.010^{* * *} \\
(0.002)\end{array}$ & $\begin{array}{l}0.024^{* * *} \\
(0.008)\end{array}$ & $\begin{array}{c}0.017^{* * *} \\
(0.003)\end{array}$ & $\begin{array}{l}0.085^{* * *} \\
(0.003)\end{array}$ & $\begin{array}{c}0.054^{* * *} \\
(0.009)\end{array}$ \\
\hline Organic Spring $\times$ Spring & $\begin{array}{c}0.013^{* * *} \\
(0.003)\end{array}$ & $\begin{array}{l}-0.001 \\
(0.002)\end{array}$ & $\begin{array}{l}0.010 \\
(0.009)\end{array}$ & $\begin{array}{c}0.000 \\
(0.002)\end{array}$ & $\begin{array}{l}-0.002 \\
(0.002)\end{array}$ & $\begin{array}{l}-0.012^{*} \\
(0.007)\end{array}$ \\
\hline \multicolumn{7}{|l|}{ Season } \\
\hline $\begin{array}{l}\text { Winter } \\
\text { Spring } \\
\text { Summer }\end{array}$ & $\begin{array}{l}-0.001 \\
(0.002) \\
-0.002 \\
(0.001) \\
-0.001 \\
(0.001) \\
\end{array}$ & $\begin{array}{c}-0.004^{* * *} \\
(0.001) \\
-0.000 \\
(0.001) \\
-0.002^{* *} \\
(0.001)\end{array}$ & $\begin{array}{c}0.020^{* * *} \\
(0.005) \\
0.004 \\
(0.005) \\
0.007 \\
(0.005) \\
\end{array}$ & $\begin{array}{c}-0.002 \\
(0.001) \\
0.001 \\
(0.001) \\
-0.002^{*} \\
(0.001) \\
\end{array}$ & $\begin{array}{c}-0.001^{*} \\
(0.001) \\
-0.002^{*} \\
(0.001) \\
-0.002^{* *} \\
(0.001)\end{array}$ & $\begin{array}{c}-0.017^{* * *} \\
(0.004) \\
-0.008^{* *} \\
(0.004) \\
-0.008^{*} \\
(0.004)\end{array}$ \\
\hline $\mathrm{R} 2$ & 0.329 & 0.464 & 0.231 & 0.694 & 0.183 & 0.651 \\
\hline LR Test & $\begin{array}{l}55.92 \\
(0.00)\end{array}$ & $\begin{array}{l}92.33 \\
(0.00)\end{array}$ & $\begin{array}{l}36.98 \\
(0.00)\end{array}$ & $\begin{array}{c}236.26 \\
(0.00)\end{array}$ & $\begin{array}{l}26.11 \\
(0.00)\end{array}$ & $\begin{array}{c}198.33 \\
(0.00)\end{array}$ \\
\hline
\end{tabular}

***,**,* resp. significant at 1\%, $5 \%$ and $10 \%$; Nb. obs.: 104 ; Standard errors into brackets; Data source: Données Kantar Worldpanel. Org., Conv., NB and PL resp. stand for organic, conventional, national brand and private label.

Table 4 shows the calculated compensated and uncompensated own-price and cross-price elasticities and the calculated expenditure elasticities for milk and eggs. For statistical inference, non linear standard errors of elasticities are obtained using the Delta method. There are less significant elasticities for eggs than for milk. The expenditure elasticities for all milk types are positive and significant. They are around 1 for conventional milk, but they are surprisingly low for organic milk ( 0.81 and 0.69 respectively for PL and NB). These results do not differ from those of others studies. Alviola and Capps (2010), Jonas and Roosen (2008), and Dhar and Foltz (2005) also find a low expenditure elasticity for organic milk. According to these authors, this may come from smaller families having lower expenditure on milk and tending to consume more organic milk than large ones. The expenditure elasticities for all egg types are positive and significant. It is less than 1 for organic eggs as for organic milk (considerably less than unit for PL organic eggs). These estimates are smaller than the 1.98 expenditure elasticity found by Boizot-Szantai, Lecocq, and Marette (2005). Our results show that organic milk and eggs (PL and NB) and PL conventional milk are necessity goods while NB conventional milk and NB and PL conventional eggs are normal goods. These latter expenditure elasticities are around 
unit.

Compensated and uncompensated elasticities are quite similar except for conventional products. This implies there is little impact of expenditures on organic milk and eggs consumption. In the following analysis, we comment on compensated elasticities as they give us pure good substitution or complementary effects without confounding by expenditure effects.

Table 4: Estimated price $\left(\epsilon_{\text {price }}\right)$ and expenditure $\left(\epsilon_{\exp }\right)$ elasticities for Milk and Eggs

\begin{tabular}{|c|c|c|c|c|c|c|c|c|c|c|}
\hline \multirow[b]{4}{*}{ PL Org. } & \multicolumn{5}{|c|}{ Milk } & \multicolumn{5}{|c|}{ Eggs } \\
\hline & $\begin{array}{l}\text { PL } \\
\text { Org. }\end{array}$ & $\begin{array}{l}\text { NB } \\
\text { Org. }\end{array}$ & $\begin{array}{c}\text { PL } \\
\text { Conv. }\end{array}$ & $\begin{array}{l}\text { NB } \\
\text { Conv. }\end{array}$ & & $\begin{array}{l}\text { PL } \\
\text { Org. }\end{array}$ & $\begin{array}{l}\text { NB } \\
\text { Org. }\end{array}$ & $\begin{array}{c}\text { PL } \\
\text { Conv. }\end{array}$ & $\begin{array}{l}\text { NB } \\
\text { Conv. }\end{array}$ & \\
\hline & \multicolumn{4}{|c|}{ Compensated $\epsilon_{\text {price }}$} & $\epsilon_{\text {exp }}$ & \multicolumn{4}{|c|}{ Compensated $\epsilon_{\text {price }}$} & $\epsilon_{\text {exp }}$ \\
\hline & -0.77 & 0.52 & $3.49^{* * *}$ & $-3.23^{* * *}$ & $0.81^{* * *}$ & -0.13 & -0.17 & 0.34 & -0.04 & $0.55^{* * *}$ \\
\hline NB Org. & $0.47^{*}$ & $-2.67^{* * *}$ & -1.52 & $3.73^{* * *}$ & $0.69^{* * *}$ & -0.21 & -0.10 & -0.60 & $0.92^{* *}$ & $0.80^{* * *}$ \\
\hline PL Conv. & $0.18^{* * *}$ & 0.09 & $-0.72^{* * *}$ & $0.45^{* * *}$ & $0.89^{* * *}$ & 0.04 & 0.02 & $-0.64^{* * *}$ & $0.59^{* * *}$ & $1.10^{* *}$ \\
\hline \multirow[t]{2}{*}{ NB Conv. } & $-0.12^{* * *}$ & $0.15^{* * *}$ & $0.31^{* * *}$ & $-0.47^{* * *}$ & $1.09^{* * *}$ & -0.00 & $0.07^{*}$ & $0.56^{* * *}$ & $-0.63^{* * *}$ & $1.12^{* *}$ \\
\hline & \multicolumn{4}{|c|}{ Uncompensated $\epsilon_{\text {price }}$} & & \multicolumn{4}{|c|}{ Uncompensated $\epsilon_{\text {price }}$} & \\
\hline PL Org. & -0.79 & 0.50 & $3.17^{* *}$ & $-3.69^{* * * *}$ & & -0.16 & -0.19 & -0.09 & 0.29 & \\
\hline NB Org. & 0.45 & $-2.69^{* * *}$ & -1.79 & $3.34^{* * *}$ & & -0.25 & -0.13 & $-0.96^{* *}$ & 0.54 & \\
\hline PL Conv. & $0.16^{* *}$ & 0.07 & $-1.07^{* * *}$ & -0.05 & & -0.01 & -0.02 & $-1.06^{* * *}$ & 0.15 & \\
\hline NB Conv. & $-0.14^{* * *}$ & $0.15^{* * *}$ & -0.12 & $-1.09^{* * *}$ & & -0.06 & 0.03 & 0.06 & $-1.22^{* * *}$ & \\
\hline
\end{tabular}

***,**,* resp. significant at 1\%,5\% and 10\% ; Data source: Données Kantar Worldpanel. Org., Conv., NB and PL resp. stand for organic, conventional, national brand and private label.

The analysis of own-price elasticities for milk shows that organic milks have negative ownprice elasticities although non significant for PL organic milk. The demand for PL organic milk is inelastic (not statistically significant) while the demand for NB organic milk is considerably elastic (-2.67). Monier, Hasssan, Nichèle, and Simioni (2009) find demand is inelastic for organic milk while Jonas and Roosen (2008) find a high price sensitivity for organic milk and mention that close substitutes exist. Glaser and Thompson (1998, 2000); Alviola and Capps (2010) also find quite large own-price elasticity for organic milk. None of these papers make the distinction between NB and PL for ecolabeled products. Furthermore, Monier, Hasssan, Nichèle, and Simioni (2009) analysis bases on the year 2005 a period where demand for organic products evolves very fast. Own-price elasticities for conventional milk and eggs (NB and PL) are negative and significant, but less than unit. The demand for conventional milk and eggs is weakly elastic. The own-price elasticities are all negative but non significant for organic eggs. Demand for organic eggs is price-rigid as is demand for PL organic milk. These results are different from Monier, Hasssan, Nichèle, and Simioni (2009) who find a -2.38 elasticity for organic eggs. They mention that consumers do not react homogeneously to organic price variations due to the maturity of the organic market, the egg market being more open than the milk one. 
Positive cross-price elasticities suggest that PL conventional milk and PL organic milk are substitutes but with asymmetries. Demand for PL organic milk increases considerably when PL conventional milk price increases (3.49\%) but demand for PL conventional milk increases much less when PL organic milk price increases $(0.18 \%)$. These elasticities are not significant for eggs.

We also find that NB organic milk and NB conventional milk are substitutes but with asymmetries. Demand for NB organic milk increases considerably when NB conventional milk price increases $(3.73 \%$ ) but demand for NB conventional milk increases much less when NB organic milk price increases $(0.15 \%)$. We find the same type of result for eggs but much smaller $(0.92 \%$ and $0.07 \%)$.

Complementary is found between NB conventional milk and PL organic milk. A $1 \%$ increase in the price of NB conventional milk leads to a high decrease in the quantity of PL organic milk $(-3.23 \%)$ whereas a $1 \%$ increase in the price of PL organic milk leads to a small decrease in the quantity of NB conventional milk $(-0.12 \%)$. The organic label may be perceived as a signal of high quality for PL milk so that PL organic milk is consumed along with NB conventional milk. These elasticities are not significant for eggs.

Result 1 (1) Own-price elasticities show that demand is elastic for national brand organic milk and inelastic for private label organic milk. Demand for organic eggs is always inelastic. (2) Cross-price elasticities show (i) substitutability between organic goods and their conventional counterparts but only within the national brand (milk and eggs) or within the private label (milk only), and (ii) complementarity between national brand conventional goods and private label organic goods (milk only).

\subsection{Demand for fair trade coffee}

Estimates of the AIDS model for coffee are presented in Table 5. Because of the adding-up condition, one equation has been deleted from the system. The demand system was estimated omitting NB conventional coffee. The log likelihood ratio test shows the joint significance of all parameters for the coffee system. We find an increase in expenditures has a negative impact on the expenditure share except for PL fair trade coffee. The significant coefficients on the year dummy indicate an upward trend for the expenditure share of PL coffee (fair trade and conventional), and no change for NB fair trade coffee. All coffee types except PL fair trade coffee display seasonal effects. Our specification enables to isolate the impact of The Fairtrade Fortnight (see Section 5). 
Table 5: Estimated AIDS model for coffee

\begin{tabular}{|c|c|c|c|}
\hline & PL FT & NB FT & PL Conv. \\
\hline Constant & $\begin{array}{c}0.006 \\
(0.028)\end{array}$ & $\begin{array}{c}0.169^{* * *} \\
(0.060)\end{array}$ & $\begin{array}{c}0.883^{* * *} \\
(0.141)\end{array}$ \\
\hline \multicolumn{4}{|l|}{ Log(Price) } \\
\hline PLFT & $\begin{array}{c}0.015 \\
(0.013)\end{array}$ & $\begin{array}{c}0.005 \\
(0.011)\end{array}$ & $\begin{array}{l}0.033^{* *} \\
(0.015)\end{array}$ \\
\hline NB FT & $\begin{array}{c}0.005 \\
(0.011)\end{array}$ & $\begin{array}{l}-0.026 \\
(0.025)\end{array}$ & $\begin{array}{l}-0.012 \\
(0.057)\end{array}$ \\
\hline PL Conv. & $\begin{array}{l}0.033^{* *} \\
(0.001)\end{array}$ & $\begin{array}{c}0.028 \\
(0.031)\end{array}$ & $\begin{array}{c}0.028 \\
(0.031)\end{array}$ \\
\hline $\log \left(\operatorname{Exp} . / P^{*}\right)$ & $\begin{array}{c}0.001 \\
(0.003)\end{array}$ & $\begin{array}{l}-0.011^{*} \\
(0.006)\end{array}$ & $\begin{array}{c}-0.075^{* * *} \\
(0.015)\end{array}$ \\
\hline Year2008 & $\begin{array}{l}0.003^{* *} \\
(0.001)\end{array}$ & $\begin{array}{l}-0.002 \\
(0.003)\end{array}$ & $\begin{array}{c}0.054^{* * *} \\
(0.006)\end{array}$ \\
\hline Fairtrade Fortnight $\times$ Spring & $\begin{array}{c}0.000 \\
(0.002)\end{array}$ & $\begin{array}{c}0.024^{* * *} \\
(0.004)\end{array}$ & $\begin{array}{c}0.000 \\
(0.009)\end{array}$ \\
\hline \multicolumn{4}{|l|}{ Season } \\
\hline Winter & $\begin{array}{l}-0.000 \\
(0.000)\end{array}$ & $\begin{array}{c}0.000 \\
(0.002)\end{array}$ & $\begin{array}{l}0.009^{*} \\
(0.005)\end{array}$ \\
\hline Spring & 0.000 & 0.000 & 0.004 \\
\hline Summer & $\begin{array}{c}(0.001) \\
0.000 \\
(0.001)\end{array}$ & $\begin{array}{c}(0.002) \\
-0.004^{* *} \\
(0.002)\end{array}$ & $\begin{array}{c}(0.005) \\
0.002 \\
(0.004)\end{array}$ \\
\hline $\mathrm{R} 2$ & 0.42 & 0.46 & 0.52 \\
\hline LR test & $\begin{array}{l}73.07 \\
(0.00)\end{array}$ & $\begin{array}{l}89.85 \\
(0.00)\end{array}$ & $\begin{array}{c}116.03 \\
(0.00)\end{array}$ \\
\hline
\end{tabular}

***, ** * resp. significant at $1 \%, 5 \%$ and $10 \%$; Nb. obs.: 104 ; Standard errors into brackets; Data source: Données Kantar Worldpanel. FT, Conv., NB and PL resp. stand for fair trade, conventional, national brand and private label.

Table 6 shows the calculated own-price, cross-price and expenditure elasticities for coffee. For statistical inference, non linear standard errors of elasticities are obtained using the Delta method. The expenditure elasticities are all positive and significant. They are around unit for PL fair trade and NB conventional coffee and less than unit NB fair trade and PL conventional coffee. PL fair trade coffee is a normal good while NB fair trade coffee is a necessity good. Less than unit elasticities have also been found as for milk and eggs as mentioned before, this may be do to a negative relationship between income and expenditure. Compensated and uncompensated elasticities are similar except for responses to PL conventional coffee and NB fair trade price changes on NB fair trade demand. This implies there is an impact of expenditures on NB fair trade coffee consumption. The following comments are based on compensated elasticities as they give us pure good substitution or complementary effects without confounding by expenditure effects.

Own-price elasticities are negative and significant for NB fair trade coffee and PL conventional coffee (not significant for PL fair trade coffee and NB conventional coffee). We find the demands for conventional coffee are inelastic. But we find a high price sensitivity $(-2.67 \%)$ for 
NB fair trade coffee suggesting that demand is considerably elastic for this product. We find as Galarraga and Markandya (2004) that demand for fair trade coffee is more elastic than the demand for its conventional counterpart. These results are different from Arnot, Boxall, and Cash (2006) who find that demand for fair trade brewed coffee is rigid and those for its conventional counterpart is elastic. Our aggregate analysis does not enable us to discriminate between heterogeneous consumers as do Hainmueller, Hiscox, and Sequeira (2015) (see Table 1).

Positive and significant cross-price elasticities show that PL fair trade coffee is a substitute for PL conventional coffee (but with some asymmetries). The same result was found for milk and eggs. A $1 \%$ increase in the price of PL conventional coffee leads to a high increase $(2.43 \%)$ in the quantity of PL fair trade coffee whereas a 1\% increase in the price of PL fair trade coffee leads to a small increase in the quantity of PL conventional coffee $(0.16 \%)$. We find quite the same result in Arnot, Boxall, and Cash (2006) as the proportion of purchasers who switch from the fair trade product to its conventional counterpart is low if the price of fair trade coffee increases, and the proportion of the fair trade coffee purchases increases as the price of conventional coffee increases.

In contrast with milk, for coffee, cross-price elasticities between NB ecolabeled good and NB conventional good are not significant. The result might stem from the specificity of brands for fair trade coffee. In contrast with organic markets, national brand manufacturers seldom sell both conventional and fair trade coffee so that when consumers switch from a national brand conventional coffee to a national brand fair trade coffee, they often switch not only to fair trade but also to another brand at the same time.

As shown for milk, negative and significant cross-price elasticities indicate that PL fair trade and NB conventional coffee are complements (but with some asymmetries). A 1\% increase in the price of NB conventional coffee leads to a high decrease $(-3.03 \%)$ in the quantity of PL fair trade coffee whereas a $1 \%$ increase in the price of PL fair trade coffee leads to a very small decrease in the quantity of NB conventional coffee $(-0.06 \%)$. Here also, the ecolabel may be perceived as a signal of high quality so that PL fair trade coffee is consumed along with the NB conventional coffee.

An additional result is worth noting. In contrast with milk and eggs, we find a substitution effect between PL conventional coffee and NB fair trade coffee. A $1 \%$ increase in the price of PL conventional coffee leads to a $1.70 \%$ increase in the quantity of NB fair trade coffee (while an increase in the price of NB fair trade coffee has no impact on the quantity of PL conventional coffee). This may reflect a move towards a national brand more that a move towards FT coffee.

Result 2 (1) Own-price elasticities show that demand is elastic for national brand fair trade coffee and inelastic for private label fair trade coffee. (2) Cross-price elasticities show (i) substitutability between fair trade coffee and its conventional counterpart but only within the private label and not within the national brand, and of (ii) complementarity between national brand conventional coffee and private label fair trade coffee. 
Table 6: Estimated price $\left(\epsilon_{\text {price }}\right)$ and expenditure $\left(\epsilon_{\text {exp }}\right)$ elasticities for coffee

\begin{tabular}{|c|c|c|c|c|c|}
\hline & PL FT & NB FT & PL Conv. & NB Conv. & \\
\hline & \multicolumn{4}{|c|}{ Compensated $\epsilon_{\text {price }}$} & $\epsilon_{\exp }$ \\
\hline PL FT & 0.06 & 0.53 & $2.43^{* *}$ & $-3.03^{* *}$ & $1.10^{* * *}$ \\
\hline NB FT & 0.17 & $-2.67^{* * *}$ & $1.70^{* *}$ & 0.79 & $0.74^{* * *}$ \\
\hline PL Conv. & $0.16^{* *}$ & -0.03 & $-0.48^{* * *}$ & 0.34 & $0.64^{* * *}$ \\
\hline \multirow[t]{2}{*}{ NB Conv. } & $-0.06^{* * *}$ & 0.05 & 0.10 & -0.09 & $1.11^{* * *}$ \\
\hline & \multicolumn{4}{|c|}{ Uncompensated $\epsilon_{\text {price }}$} & \\
\hline PL FT & 0.09 & 0.37 & $2.56^{* * *}$ & $-3.02^{* * *}$ & \\
\hline NB FT & 0.12 & $-1.55^{* * *}$ & 0.85 & 0.57 & \\
\hline PL Conv. & $0.17^{* * *}$ & -0.02 & $-0.66^{* * *}$ & $0.50^{*}$ & \\
\hline NB Conv. & $-0.06^{* * *}$ & -0.03 & $0.14^{*}$ & -0.12 & \\
\hline
\end{tabular}

$* * *, * *,{ }^{*}$ resp. significant at $1 \%, 5 \%$ and $10 \%$; Data source: Données Kantar Worldpanel. FT, Conv., NB and PL resp. stand for fair trade, conventional, national brand and private label.

\section{Impact of information campaigns on ecolabeled good demand}

From our econometric results, we found that The Organic Spring, "Le Printemps Bio", has a positive impact on the demand for PL organic milk but a negative impact on the demand for PL conventional eggs. The Fairtrade Fortnight, "La Quinzaine du Commerce Equitable", has a positive impact on the demand for NB fair trade coffee. Consumers behave as if they reward PL organic milk and NB fair trade coffee but penalise PL conventional eggs as a result of information campaigns. A relevant question is whether information campaigns have lasting effects. We introduced a lagged information campaign dummy in the AIDS models. This dummy was equal to one during the week following the information campaign and zero otherwise. We found no lasting effects on the following week.

To evaluate the impact of information campaigns on the magnitude of the demand changes, we used the AIDS model estimates to calculate the predicted expenditure shares for each milk, eggs and coffee type as in Lusk (2010). Predicted shares are displayed in Figure 4, Figure 5, and Figure 6.

Consider first the impact of information campaigns on the predicted expenditure share of pooled ecolabeled products (NB and PL). The impact of The Organic Spring is positive on the predicted expenditure share of ecolabeled milk (in 2007, $4.1 \%$ to $5.1 \%$; in $2008,4.6 \%$ to $5.8 \%$ ). The Organic Spring has no impact on the predicted expenditure share of ecolabeled eggs. The impact of The Fairtrade Fortnight is positive on the predicted expenditure share of ecolabeled coffee (in $2007,5.9 \%$ to $8.4 \%$; in $2008,5.9 \%$ to $8.3 \%$ ). 
Consider now the impact of information campaigns on each product. For milk and coffee, we observe important increases in the predicted expenditure shares of some ecolabeled products. The expenditure share of the PL organic milk increases by around two third after the information campaign (in 2007, $1.8 \%$ to $3 \%$; in 2008, $2 \%$ to $3.3 \%$ ) while the expenditure share of the NB fair trade coffee increases by more than $50 \%$ (in 2007, $4.7 \%$ to $7.2 \%$; in $2008,4.3 \%$ to $6.7 \%)$. Figure 4 shows the predicted share of PL organic milk increases at the expense of NB conventional milk. The expenditure share of NB organic milk is quite stable (in 2007, 2.3\% to $2.1 \%$; in $2008,2.6 \%$ to $2.5 \%$ ). Figure 6 shows that the predicted share of NB fair trade coffee increases at the expense of NB conventional coffee. The expenditure share of PL fair trade coffee is stable (in 2007, 1.2\%; in 2008, 1.6\%). Figure 5 shows that predicted shares of organic eggs are stable. The expenditure share of PL conventional eggs decreases by around $3 \%$ after the information campaign (in $2007,43.2 \%$ to $42 \%$; in $2008,46.2 \%$ to $45 \%$ ). The predicted share for PL conventional eggs decreases for the benefit of NB conventional eggs.

It is notable that The Organic Spring negatively impacts predicted shares of PL conventional eggs, although this effect is small. For this specific product, consumers penalise PL conventional goods and turn to NB conventional products. This behaviour could be interpreted as related to animal welfare issues. For example, Berndsen and van der Pligt (2004) report that some consumers associate "slightly negative feelings, morally unacceptable issues, and risks for both their health and the environment" to the consumption of meat. The same feelings might explain our results on the impact of The Organic Spring on eggs consumption. Organic eggs production is perceived as more acceptable since chickens must be fed only with organic feed, have access outdoor and have more space. Instead of increasing organic eggs consumption out of positive feelings, information campaigns might trigger negative feelings such as guilt and lead to reduction of conventional good consumption.

Result 3 The Organic Spring has a large positive impact on the predicted share of private label organic milk $(+33 \%)$ but a small negative impact on the predicted share of private label conventional eggs $(-3 \%)$. The Fairtrade Fortnight has a large positive impact on the predicted share of national brand fair trade coffee $(+50 \%)$. None of these effects last in the following week. Information campaigns are at the expense of national brand conventional milk and coffee and benefit national brand conventional eggs. 
Without information campaign 2007
PL organic

PL conventional

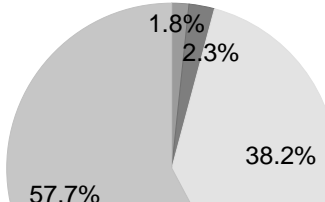

$57.7 \%$
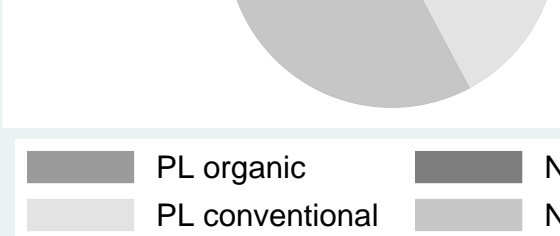

NB organic

NB conventional

\section{With information campaign 2007}

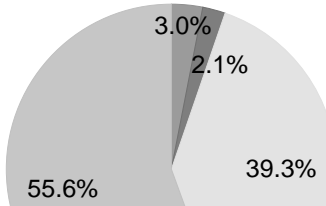

PL conventional

NB conventional

Without information campaign 2008

With information campaign 2008
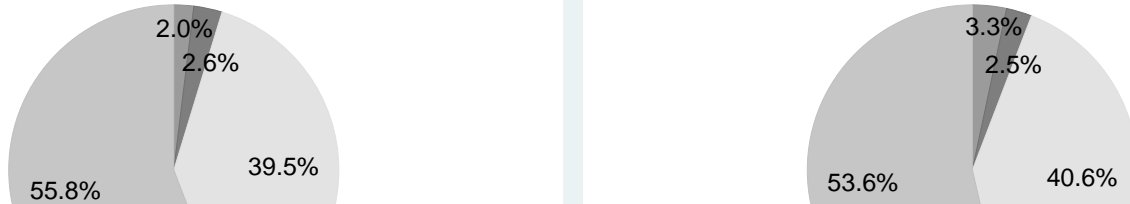

PL organic

NB organic

NB conventional

PL organic

$\mathrm{PL}$ conventional
NB organic

NB conventional

Figure 4: Predicted expenditure shares for milk 
Without information campaign 2007

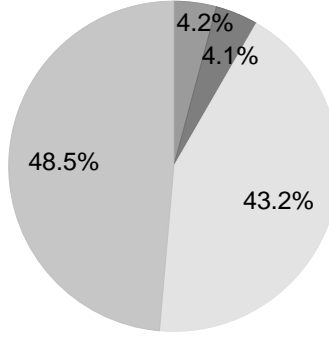

PL organic

PL conventional
NB organic

NB conventional

\section{With information campaign 2007}

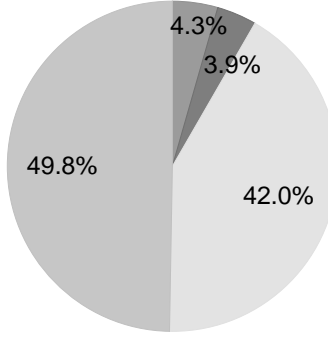

PL organic

NB organic

PL conventional

NB conventional

Without information campaign 2008

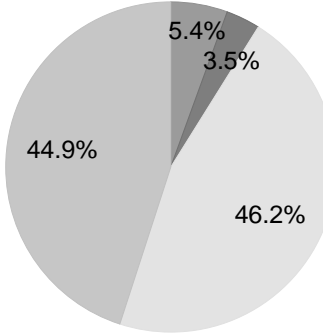

PL organic

$\mathrm{PL}$ conventional
NB organic

NB conventional
With information campaign 2008

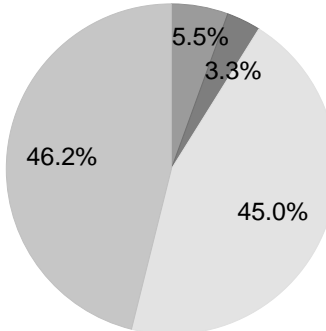

PL organic

NB organic

PL conventional

Figure 5: Predicted expenditure shares for eggs 
Without information campaign 2007

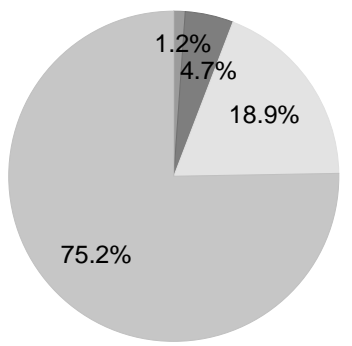

PL fair trade

PL conventional
NB fair trade NB conventional

\section{With information campaign 2007}

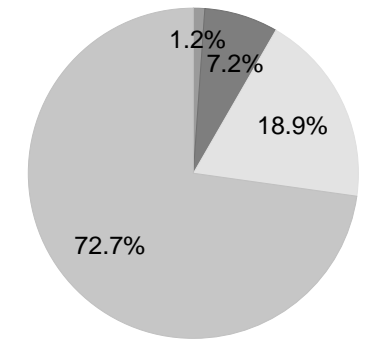

PL fair trade

NB fair trade

PL conventional

Without information campaign 2008

With information campaign 2008

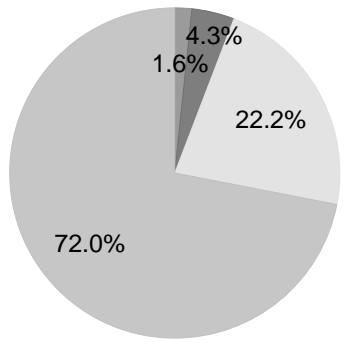

PL fair trade

NB fair trade

$\mathrm{PL}$ conventional

NB conventional

$P L$ fair trade

NB fair trade

PL conventional

NB conventional

Figure 6: Predicted expenditure shares for coffee 


\section{Conclusion}

Information policies are considered as alternatives to market-based and command-and-control policies. In this article, we analyzed the impact of two types of information policies on consumer behavior, ecolabels that provide information to consumers on food processing, and information campaigns that aim to raise consumer awareness on a given issue. We used demand system estimation to elicit the demand for organic and fair trade products from scanner data in France in a period where retailer began to play an important role in ecolabeled markets. We were especially focusing on two issues.

First, we sought to estimate demand for organic and fair trade food products as a function of the good having a national brand or a private label since, to our knowledge, no article in the literature distinguishes the national brand from the private label. In the literature, demand for ecolabeled goods is found elastic and sometimes very elastic. We also found that the demand for ecolabeled goods (milk and coffee) is elastic but only for the national brand goods. We also find expenditure elasticities are smaller than unit for all ecolabeled goods (but around unit for national brand coffee). The same results are found in the literature mainly for articles dealing with milk. In the literature, estimated cross-price elasticities show that ecolabeled goods and their conventional counterpart are substitutes except for meat (complements). Depending on the considered product, we found substitutability but only within the national brand goods or within the private label goods, and complementarity between national brand conventional goods and private label ecolabeled goods. Thus, we contribute to the literature on the demand for ecolabeled goods by distinguishing national brands and private labels.

These results shed some light on the debate among fair trade promoters about the opportunity to use retail stores as marketing channels. At the period of our study, some fair trade manufacturers chose to create their own stores to market ecolabeled products while others sell their products at conventional retail stores. These two positions still exist today. Those who avoid retail stores (for example, Artisans du Monde) do so for ethical reasons claiming that even the marketing channel should use fair trade methods (Poret and Chambolle (2007); DubuissonQuellier and Lamine (2008)). We studied substitutability and complementarity between private label and national brand ecolabeled goods. Our results provide some evidence on the impact of retailers strategies on the demand for national brand ecolabeled goods. We found retailers pricing of the private label conventional good has small impacts. Retailers pricing of the private label organic milk is found to have a significant decreasing effect on the demand for national brand organic milk; but decreases in the price of the private label fair trade coffee had no impact on the demand for national brand fair trade coffee. No effect was found for eggs. These results are contingent on our data, at a time period where large retailers began to play an important role in ecolabeled markets in France. Analyzing the actual demand for ecolabeled national brand and private label goods, now that the market is more mature, is a challenging topic for future research.

Second, we wanted to determine the impact of information campaigns on ecolabeled food 
demand. We find differing impacts on organic and fair trade goods. Information campaigns benefit the private label good in the case of organic milk whereas they benefit the national brand good in the case of fair trade coffee. As for eggs, information campaigns are detrimental to private label conventional eggs. This mimics the findings of Kotchen and Moore (2008) on electricity demand where consumers either pay a price premium for green electricity or voluntary restraint from conventional electricity with negative externalities. In our study, after the information campaign, consumers are willing to pay a premium for organic milk and fair trade coffee but voluntarily restrain from conventional eggs consumption. Finally, we found no lasting impact of information campaigns. However, they may have a long term effect and explain in part the positive effect of the year dummy (upward trend in ecolabeled products consumption). Again, testing for the impact of information campaigns using a longer time period including more recent data is an interesting topic for future research.

\section{References}

Alviola, P. A., And O. J. CApps (2010): "Households Demand Analysis of Organic and Conventional Fluid Milk in the United States Based on the 2004 Nielsen Homescan Panel," Agribusiness, 26(3), $369-388$.

Anders, S., AND A. Moeser (2008): "Assessing the demand for value-based organic meats in Canada: a combined retail and household scanner-data approach," International Journal of Consumer Studies, 32(5), 457-469.

ARMAND-BALMAT, C. (2002): “Comportement du consommateur et produits biologiques: le consentement à payer pour la caractéristique biologique," Revue d'Economie Politique, 112(1), $33-46$.

ARnot, C., P. C. Boxall, And S. B. CASH (2006): “Do Ethical Consumers Care About Price? A Revealed Preference Analysis of Fair Trade Coffee Purchases," Canadian Journal of Agricultural Economics, 54, 555 - 565.

Berges-Sennou, F., P. Bontems, and V. Requillart (2004): “Economics of Private Labels: A Survey of Literature," Journal of Agricultural and Food Industrial Organization, 2(1).

Berndsen, M., And J. VAn Der Pligt (2004): “Ambivalence towards meat," Appetite, 42(1), $71-78$.

Bjorner, T. B., L. G. HANSEN, AND C. S. Russell (2004): “Environmental labeling and consumer choice: an empirical analysis of the effect of the Nordic Swan," Journal of Environmental Economics and Management, 47(3), $411-434$.

Boizot-Szantai, C., S. LecocQ, and S. Marette (2005): “Common Labels and Market Mechanisms," Discussion paper, Center for Agricultural and Rural Development (CARD), Iowa State University. 
Casadesus-Masanell, R., M. Crooke, F. Reinhardt, and V. Vasishth (2009): “Households' Willingness to Pay for "Green" Goods: Evidence from Patagonia's Introduction of Organic Cotton Sportswear," Journal of Economics E Management Strategy, 18(1), 203-233.

Deaton, A., And J. Muellbauer (1980): “An Almost Ideal Demand System," The American Economic Review, 70(3), pp. 312-326.

Dhar, T., AND J. D. Foltz (2005): “Milk by Any Other Name...Consumer Benefits from Labeled Milk," American Journal of Agricultural Economics, 87(1), 214-228.

DubuisSON-QUelLier, S., AND C. LAMiNe (2008): “Consumer involvement in fair trade and local food systems: delegation and empowerment regimes," GeoJournal, 73(1), 55-65.

GalarragA, I., AND A. MARKAndya (2004): “Economic Techniques to Estimate the Demand for Sustainable Products: A Case Study for Fair Trade and Organic Coffee in the United Kingdom," Economia Agraria y Recursos Naturales, 4(7), 109-134.

Glaser, L. K., AND G. D. ThOMPSON (1998): “Demand For Organic And Conventional Frozen Vegetables," 1998 Annual meeting of the American Agricultural Economics Association, August 811, Nashville, TN.

(2000): "Demand For Organic And Conventional Milk," 2000 Annual Meeting of the Western Agricultural Economics Association, June 29-July 1, Vancouver, British Columbia.

Hainmueller, H., M. J. Hiscox, And S. Sequeira (2015): “Concumer Demand for Fair Trade Label: Evidence from a Multistore Field Experiment," The Review of Economics and Statistics, 97(2), 242-256.

JONAS, A., AND J. RoOSEN (2008): “Demand for milk labels in Germany: organic milk, conventional brands, and retail labels," Agribusiness, 24(2), 192-206.

Kiesel, K., And S. B. Villa-BoAs (2007): "Got organic milk? Consumer valuations of milk labels after the implementation of the USDA organic seal," Journal of Agricultural and Food Industrial Organization, 5, 1-38.

Kotchen, M. J., And M. R. Moore (2008): “Conservation: From Voluntary Restraint to a Voluntary Price Premium," Environmental and Resource Economics, 40(2), 195-215.

LUSK, J. (2010): "The Effect of Proposition 2 on the Demand for Eggs in California," Journal of Agricultural \& Food Industrial Organization, 8(1), 1-20.

Monier, S., D. Hasssan, V. Nichèle, And M. Simioni (2009): “Organic Food Consumption Patterns," Journal of Agricultural and Food Industrial Organization, 7(2), 1-23.

Poret, S., and C. Chambolle (2007): “Fair Trade Labeling: Inside or Outside Supermarkets?," Journal of Agricultural \& Food Industrial Organization, 5. 
Roheim, C. A., F. Asche, And J. I. SAntos (2011): “The Elusive Price Premium for Ecolabelled Products: Evidence from Seafood in the UK Market," Journal of Agricultural Economics, 62(3), 655-668.

SCHOllenberG, L. (2012): "Estimating the hedonic price for Fair Trade coffee in Sweden," British Food Journal, 114(3), 428 - 446.

Sun, C.-H. J., F.-S. ChiAnG, M. Owens, And D. SQuires (2017): “Will American consumers pay more for eco-friendly labeled canned tuna? Estimating US consumer demand for canned tuna varieties using scanner data," Marine Policy, 79, 62-69.

Teisl, M. F., B. RoE, And R. L. Hicks (2002): “Can Eco-Labels Tune a Market? Evidence from Dolphin-Safe Labeling," Journal of Environmental Economics and Management, 43(3), 339 - 359.

Yussefi-Menzler, M., H. Willer, And N. SOREnSEn (2010): The World of Organic Agriculture: Statistics and Emerging Trends 2008. Taylor \& Francis. 


\section{CEE-M Working Papers1 - 2018}

WP 2018 - 01: $\quad$ Ilaria Brunetti., Mabbel Tidball, $\&$ Denis Couvet « Relationship Between Biodiversity and Agricultural Production »

WP 2018 - 02: $\quad$ Phillippe Le Coent, Raphaële Préget \& Sophie Thoyer « Do farmers follow the herd? The influence of social norms in the participation to agri-environmental schemes.»

WP 2018 - 03: $\quad$ Ludivine Roussey \& Raphael Soubeyran

« Overburdened judges »

WP 2018 - 04: $\quad$ Nicolas Quérou

«Interacting collective action problems in the Commons »

WP 2018 - 05: $\quad$ Karine Constant \& Marion Davin

«Unequal vulnerability to climate change and the transmission of adverse effects through international trade»

WP 2018 - 06: $\quad$ Henrik Andersson \& Emmanuelle Lavaine

« Nitrates and property values: evidence

from a french market intervention »

WP 2018 - 07: $\quad$ Mamadou Gueye, Nicolas Querou \& Raphaël Soubeyran

«Does equity induce inefficiency? An experiment on coordination »

WP 2018 - 08: $\quad$ Douadia Bougherara \& Laurent Piet

« On the role of probability weighting on WTP for crop insurance with and without yield skewness »

WP 2018 - 09: $\quad$ Douadia Bougherara, Carole Ropars-Collet \& Jude Saint-Gilles « Impact of private labels and information campaigns on organic and fair trade food demand»

1 CEE-M Working Papers

Contact : laurent.garnier@inra.fr/ 0499613121 